\title{
Escape history and proportion of farmed Atlantic salmon Salmo salar on the coast and in an adjacent salmon fjord in Norway
}

\author{
Tonje Aronsen*, Eva M. Ulvan, Tor F. Næsje, Peder Fiske \\ Norwegian Institute for Nature Research, 7485 Trondheim, Norway
}

\begin{abstract}
To gain more knowledge about escaped farmed salmon Salmo salar in the wild, we investigated the proportion of escapees, body length at escape, proportion escaped as smolts/ post-smolts $(\leq 300 \mathrm{~mm})$ and number of winters in the wild (winter zones in the growth pattern in the scale samples) in catches on the Norwegian coast and in an adjacent fjord from 2013 to 2017. The mean proportion of escapees was higher on the coast $(26 \%)$ than in the fjord (4\%), and escapees caught on the coast had a slightly larger mean body length at escape $(607 \mathrm{~mm})$ than in the fjord $(557 \mathrm{~mm})$. However, the mean proportion escaped as smolts/post-smolts did not differ significantly between the coast $(8 \%)$ and the fjord $(11 \%)$. There was also no significant difference in the mean proportion of farmed salmon with 1 or more winter zones after escape $(50 \%$ on the coast and $56 \%$ in the fjord). The proportions of escapees with 1,2, 3 or 4 winter zones after escape were 28 , 20,2 and $0.4 \%$ in catches on the coast and 30,21 and $4 \%$ in catches in the fjord, respectively. This study found that the proportion of escapees was considerably higher in coastal waters than in the fjord. Escapees consisted of farmed salmon from several escape events over several years, and approximately $50 \%$ of the escapees had one or more winter zones after escape. Thus, escaped farmed salmon may pose a threat to wild salmon populations for several years after the escape event.
\end{abstract}

KEY WORDS: Atlantic salmon · Escapees · Aquaculture

\section{INTRODUCTION}

Norwegian commercial production of farmed Atlantic salmon Salmo salar L. started in the 1970s, and in 2017 the biomass produced exceeded the biomass of Norway's catch of wild salmon by a factor of more than 1500. Production of farmed salmon in Norway was $1220000 \mathrm{t}$, while the reported mass of the catch of wild salmon was $782 \mathrm{t}$ (Anon 2018b). Presence of escaped farmed salmon in Norwegian rivers was first documented in the 1980s (Gausen \& Moen 1991, Lund et al. 1991). Escapees may spawn with wild conspecifics, and genetic introgression of farmed salmon into wild populations has negative effects on the wild populations (Hindar et al. 1991, Taranger et al. 2015, Bolstad et al. 2017, Glover et al.

${ }^{*}$ Corresponding author: tonje.aronsen@nina.no
2017) due to the reduced fitness (Fleming et al. 2000, McGinnity et al. 2003, Skaala et al. 2012) and lower genetic variation in farmed salmon (Mjølnerød et al. 1997, Skaala et al. 2004, 2005, Karlsson et al. 2010).

Presence of escaped farmed salmon in rivers has been monitored in Norway since 1989 (Fiske et al. 2006, Diserud et al. 2019, Glover et al. 2019), and monitoring in rivers was further increased when a national monitoring program was established in 2014 (Glover et al. 2019). Between 2014 and 2017, the mean proportion of escaped farmed salmon in river catches during the summer angling season ranged from $2.8 \%$ in 2017 to $5.4 \%$ in 2014 (mean $=3.9 \%$ ), while the proportion of escaped farmed salmon in catches after the end of the angling season ranged from $3.8 \%$ in 2017 to $11.2 \%$ in 2014 (mean $=7.7 \%$ ) 
(Anon 2018a). Between 2013 and 2017, the number of escaped farmed salmon reported to the Norwegian Directorate of Fisheries varied from 15000 in 2017 to 287000 in 2014 (mean $=160400)(\mathrm{https}: / / \mathrm{www}$. fiskeridir.no). Reported numbers are likely an underestimation of the real number of escapees (Fiske et al. 2006, Skilbrei et al. 2015a).

Farmed salmon that escape as smolts/post-smolts or adults appear to have high mortality (Jonsson \& Jonsson 2006, Whoriskey et al. 2006, Skilbrei et al. 2015a), which may be even higher for adult escapees than for smolts/post-smolts (Skilbrei et al. 2015a). Causes for the high mortality of escapees include predation and the inability to switch to live prey in the wild (Whoriskey et al. 2006, Olsen \& Skilbrei 2010). However, even though the proportion of escapees that return to freshwater to spawn may be relatively low, escaped farmed salmon are classified as one of the most severe threats to wild salmon populations due to the high initial number of escapees (Taranger et al. 2015, Forseth et al. 2017, Anon 2018b). Escaped farmed salmon have been documented at spawning grounds in Norwegian rivers since 1986 (Gausen \& Moen 1991), and genetic changes due to introgression have been reported (Skaala et al. 2006, Glover et al. 2013). A study by Karlsson et al. (2016) found significant genetic introgression from farmed salmon in almost half of the studied Norwegian salmon populations (109 rivers).

Farmed salmon that escape as smolts or post-smolts will likely be more similar to wild salmon than those that escape after a longer time in the sea cages, both in appearance (Fiske et al. 2005, Jørgensen et al. 2018) and behaviour (Fleming et al. 1997). Skilbrei (2010b) found that the marine migratory behaviour of farmed smolts/post-smolts released in the spring and summer was similar to the migratory pattern of wild salmon, and the fish quickly migrated towards the open ocean. This migratory behavior of smolts/post-smolts appeared to be well developed for at least $6 \mathrm{wk}$ after they were transferred to net pens as smolts in the spring (Skilbrei 2010b). Migratory behaviour of farmed salmon released as post-smolts during autumn was less pronounced and the fish remained close to the release site for several months after release (Skilbrei 2010b).

Farmed salmon that escaped as smolts/post-smolts have been found in the feeding areas of wild salmon (Hansen et al. 1993, Jacobsen \& Hansen 2001, Jensen et al. 2013). Returning adult farmed salmon released as smolts and post-smolts mostly returned to the area of release (Skilbrei 2010a, Skilbrei et al. 2015a), which suggests some level of homing for farmed salmon released in the marine phase. However, the farmed smolts and post-smolts that did not return to the area of release were spread over vast distances (Skilbrei 2010a). Adult escapees may remain close to the release site for months after escape and may enter nearby rivers to spawn when sexually mature (Skilbrei \& Jørgensen 2010). Other adult escapees may disperse far from the site of escape (Hansen 2006, Hansen \& Youngson 2010, Skilbrei et al. 2010) and likely move with the currents until they are ready to spawn (Hansen 2006, Whoriskey et al. 2006, Skilbrei et al. 2010).

Mark and release studies have provided important information on the survival and migration pattern of salmon released at different sizes and at different times of the year (Hansen \& Jonsson 1991, Hansen 2006, Skilbrei \& Jørgensen 2010, Skilbrei et al. 2015a). Less is known, however, about the escape history of salmon from accidental escape events. Studies using fatty acid profiling suggest that the majority of the escapees found in nature are newly escaped individuals (Skilbrei et al. 2015b, Quintela et al. 2016, Madhun et al. 2017). Among escaped farmed salmon caught in the fjord and rivers in the Hardangerfjord basin in southwestern Norway in 2011, $24 \%$ of the escapees had had likely escaped as smolts/post-smolts, and $61 \%$ of the caught escapees were recently escaped farmed salmon (Skilbrei et al. 2015b). In the Etne River in southwestern Norway, $100 \%$ of the investigated farmed salmon caught in 2013 escaped the same year they entered the river (Quintela et al. 2016), and the same was the case for $91 \%$ of the farmed salmon caught at that site in 2014 (Madhun et al. 2017).

This study investigates the proportion and escape history of farmed salmon in an area with intense farming activity on the coast of Norway and in a large adjacent salmon fjord during the returning spawning migration of wild salmon. We analyzed the growth pattern of scales from salmon caught in bag nets and bend nets to determine the escape history of the farmed salmon in the catches. Recorded variables were the back-calculated size at escape, proportion of escapees that escaped soon after they were released into the sea as smolts/post-smolts (size $\leq 300 \mathrm{~mm}$ ) and proportion of escapees which had spent a winter or more in the wild after escape (based on winter zones in the scale growth pattern).

\section{MATERIALS AND METHODS}

\subsection{Sample collection}

Scales from Atlantic salmon were collected from fish caught on the Norwegian coast (Kvaløya Island) 
and in a nearby fjord (Namsfjord) (Fig. 1) between 2013 and 2017. The Namsfjord contains 10 salmon rivers, including the major salmon river, Namsen River, in central Norway $\left(64-65^{\circ} \mathrm{N}\right)$. Scale samples were collected from fish caught using bag nets or bend nets on the coast and bag nets in the fjord. From each fish, a minimum of 8 scales were removed from slightly above the lateral line, between the dorsal and adipose fins (Warner \& Havey 1961, Jensen \& Johnsen 1982). Total length was measured to the closest $\mathrm{cm}$ for each fish. It was also noted if the fish was missing an adipose fin, which is an indicator of cultivated fish released for stocking purposes.

On the coast, scale samples were mostly collected from salmon caught in bag nets but also a few fish caught in bend nets at 3 different locations off Kvaløya Island (Fig. 1, net 1: $65^{\circ} 1^{\prime} 47^{\prime \prime} \mathrm{N}, 11^{\circ} 6^{\prime} 15^{\prime \prime} \mathrm{E}$, net 2: $65^{\circ} 0^{\prime} 9^{\prime \prime} \mathrm{N}, 11^{\circ} 9^{\prime} 9^{\prime \prime} \mathrm{E}$, net 3: $64^{\circ} 59^{\prime} 57^{\prime \prime} \mathrm{N}$, $11^{\circ} 9^{\prime} 13^{\prime \prime}$ E). Scale samples were collected between June 3 and August 9 in 2013, June 3 and August 22 in 2014, June 1 and August 11 in 2015, June 1 and August 27 in 2016 and June 1 and August 20 in 2017. For the majority of the sampling periods, the fish were caught in 2 bag nets (mesh size $58 \mathrm{~mm}$ ), but for the last 2-3 wk of each fishing season, 2 bend nets were used (mesh size 64-66 mm) due to rough weather conditions. All the fish caught in the bag nets or bend nets at Kvaløya were euthanized.

At the fjord location, scale samples were collected from salmon caught in bag nets between May 16 and September 10 in 2013, May 15 and September 10 in 2014, May 10 and September 16 in 2015, May 3 and September 21 in 2016 and May 1 and September 15 in 2017. Note that the sampling period started earlier and lasted longer in the fjord than on the coast. The 2 bag nets (mesh size $58 \mathrm{~mm}$ ) were located on both sides of the fjord south of Otterøya in the Namsfjord

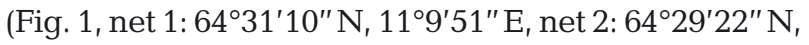
$\left.11^{\circ} 10^{\prime} 45^{\prime \prime} \mathrm{E}\right)$. During the commercial salmon fishing season in the sea (June 10 to July 27), all salmon were euthanized, while before June 10 and after July 27, fish classified as wild fish based on morphology and without serious damage from nets or predation were released back into the sea after data collection. Due to fishing regulations, the bag nets were closed between $3 \mathrm{pm}$ Friday and $3 \mathrm{pm}$ Monday during the commercial fishing season, but were open at all times outside this period. Salmon classified as escaped farmed salmon,

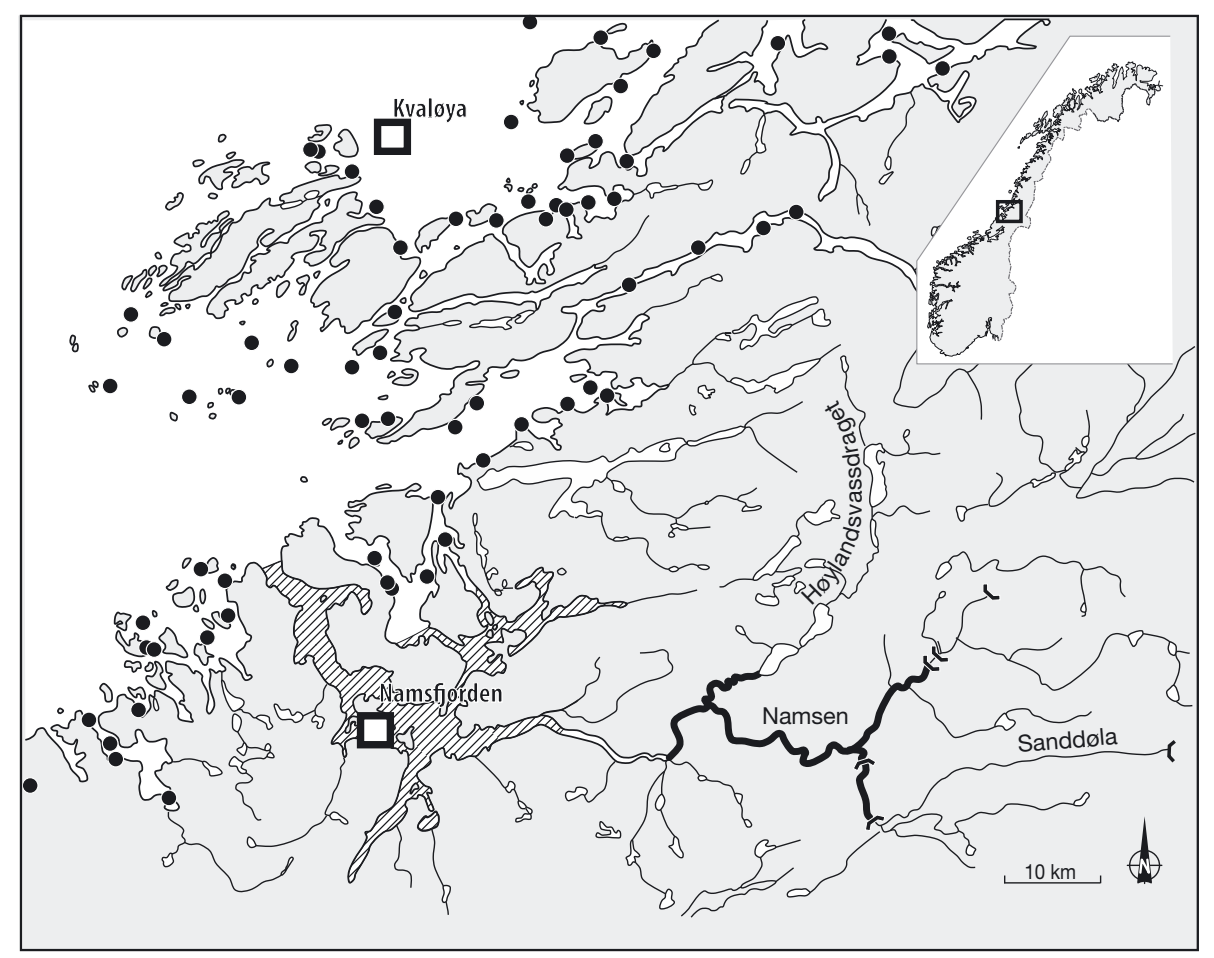

Fig. 1. Kvaløya Island, the Namsfjord and the River Namsen system, showing the areas (squares) where Atlantic salmon were captured with bag nets or bend nets on the coast and with bag nets in the fjord. The shaded area indicates the extent of the protected area of the national salmon fjord and black dots indicate Atlantic salmon farms. Data on farm locations and the protection zone was found on the website of the Norwegian Directorate of Fisheries (https://www.fiskeridir.no). The inset shows the location of the study site in Norway. Graphics: Kari Sivertsen, NINA 
based on morphology, were euthanized outside and during the commercial season.

Most of the fish on the coast and in the fjord were caught in bag nets with mesh size $58 \mathrm{~mm}$. This mesh size will allow fish smaller than approximately $57 \mathrm{~cm}$ to escape (T. F. Næsje et al. unpubl. data). Therefore, the catches were not representative of the smaller salmon migrating to the rivers. The shortest possible salmon migration route from Kvaløya to the Namsfjord was approximately $80 \mathrm{~km}$. Bag nets in the Namsfjord were located approximately $19 \mathrm{~km}$ from the mouth of the river Namsen. The majority of both the wild $(80 \%)$ and farmed $(74 \%)$ salmon caught in the bag nets in the Namsfjord migrate to the river Namsen (Moe et al. 2016). Salmon catches in the fjord should therefore be representative of the river Namsen except for an underestimation of salmon of small sizes $(<57 \mathrm{~cm})$. Reported total catch of salmon in the river Namsen during the commercial angling season varied between 7307 and 9935 in the years 2013-2017 (Statistics Norway: https://www.ssb.no/).

\subsection{Scale analysis}

Impressions of the scales were made by placing a minimum of 6 scales on a slide made of cellulose acetate and making an imprint with a roller. Based on the growth pattern in the scale samples, the salmon were classified as farmed or wild. At least 6 characters differ, to varying degrees, between farmed and wild salmon: smolt size, smolt age, the transition from fresh to salt water, sea winter zones, summer checks and replacement scales (Lund \& Hansen 1991, Fiske et al. 2005). In periods with low growth in the wild, such as when food is limited or when water temperatures are low, the spacing between circuli in the scales is smaller than during periods with higher growth (Lund \& Hansen 1991, Fiske et al. 2005, ICES 2011). This is characteristic for winters in the wild and also for the period after escape for farmed salmon. For the farmed salmon, the growth pattern in the scales and the length at capture were used to estimate the back-calculated length $(\mathrm{mm})$ when the smolts were transferred to the sea cages, the back-calculated length $(\mathrm{mm})$ at escape (i.e. the length when the growth pattern indicated a change from a captive environment to the wild environment) and the number of winter zones after escape (Lund \& Hansen 1991, Fiske et al. 2005, ICES 2011). If the back-calculated length at escape was $\leq 300 \mathrm{~mm}$, the farmed salmon was considered to have escaped in the smolt or post-smolt stage. If there were no post escape sea-winter zones in the scales, the fish was considered to have escaped the same year as caught. For fish that had one or more winter zones after escape, it was difficult in some cases to determine the exact number of winter zones in the scale, and the minimum number of years in the wild was used in analyses. Number of winter zones after escape may therefore be underestimated. Based on scale analysis, it can be difficult to separate cultivated salmon released as smolts and farmed salmon that escape as smolts, since fish cultivated for stocking purposes and farmed salmon have similar backgrounds in captivity. However, it is common practice to mark cultivated fish by cutting off the adipose fin. In this study, individuals released/escaped as smolts based on scale analysis and with an intact adipose fin were included as escaped farmed salmon.

\subsection{Data analysis}

Differences in the proportion of farmed salmon on the coast and in the fjord between 2013 and 2017, the effect of location on the proportion of salmon escaped as post-smolts $(\leq 300 \mathrm{~mm})$ and the proportion of salmon with winter zones after escape were investigated using generalized mixed effects models (GLMMs) with a binomial link function and year as a random factor. Wild salmon, cultured salmon and salmon of unknown origin were given the value 0 , while farmed salmon were given the value 1 . Fish that had a back-calculated length at escape $>300 \mathrm{~mm}$ were classified as escaped as adults (assigned as 0), while fish that had a back-calculated length at escape $\leq 300 \mathrm{~mm}$ were classified as escaped as smolts/ post-smolts (assigned as 1). Similarly, fish that had no winter zones in their scales after escape were classified as newly escaped (assigned as 0), while fish with one or more winter zones in their scales after escape were classified as escaped earlier (assigned as 1). Farmed salmon that escape as smolts/post-smolts are expected to migrate to the sea shortly after escape (Skilbrei 2010b) and are too small to be caught in the bag nets/bend nets in the fjord and on the coast. Newly escaped farmed salmon caught in the fjord and on the coast will therefore be farmed salmon escaped after some time in the sea cages. We therefore repeated the GLMM analysis of the effect of location on the proportion of escapees with winter zones after escape with adult escapees only. Potential differences between the locations in length at escape were tested using a LMM with year as a random factor. 
Sample sizes varied between the escape history parameters, since the information obtained from scale samples depends on the quality of the sample. Sample sizes for each variable for each year are given in Tables 1 \& 2 . The lmerTest package (Kuznetsova et al. 2017) in R was used to obtain p-values for the LMM model, while the lme4 package (Bates et al. 2015) was used to run the GLMM models. All statistical analyses were done using $\mathrm{R}$ version 3.4.0 (R Core Team 2017).

\section{RESULTS}

\subsection{Proportion of escaped farmed salmon in catches}

Catches on the coast had higher proportions of escaped farmed Atlantic salmon than catches in the fjord (GLMM: intercept (coast) estimate $( \pm \mathrm{SE})=$ $-1.09 \pm 0.17$, contrast fjord $=-2.18 \pm 0.07, z=$ $-29.36, \mathrm{p}<0.0001)$. Mean $( \pm \mathrm{SE})$ proportion of escaped farmed salmon on the coast was $26 \pm 3 \%$, and the variation among years was $17-37 \%$. In the fjord, the mean proportion was $4 \pm 0.8 \%$, and the variation among years was 1-6\% (Table 1, Fig. 2). Proportion of escapees was still higher on the coast than in the fjord when only including fish caught in the time period when both locations were sampled (GLMM: intercept (coast) estimate $( \pm \mathrm{SE})=$ $-1.09 \pm 0.15$, contrast fjord $=-2.17 \pm 0.09, z=$ $-24.97, \mathrm{p}<0.0001)$. The mean $( \pm \mathrm{SE})$ proportion of escapees was $26 \pm 3$ and $4 \pm 0.7 \%$ on the coast and in the fjord, respectively.

Table 1. Number (N) of wild and farmed Atlantic salmon, total number of salmon and percentage of escaped farmed salmon in the catches on the Norwegian coast and in the Namsfjord for the years 2013-2017. The total number of salmon caught includes cultivated individuals and individuals that could not be classified

\begin{tabular}{|cccccc|}
\hline & Year & $\begin{array}{c}\text { N } \\
\text { wild }\end{array}$ & $\begin{array}{c}\text { N } \\
\text { farmed }\end{array}$ & $\begin{array}{c}\text { N } \\
\text { total }\end{array}$ & $\begin{array}{c}\text { \% farmed } \\
\text { salmon }\end{array}$ \\
\hline Coast & 2013 & 246 & 148 & 401 & 37 \\
& 2014 & 373 & 153 & 583 & 26 \\
& 2015 & 554 & 208 & 816 & 26 \\
& 2016 & 484 & 165 & 691 & 24 \\
& 2017 & 622 & 126 & 763 & 17 \\
Fjord & 2013 & 1046 & 68 & 1130 & 6 \\
& 2014 & 1192 & 65 & 1291 & 5 \\
& 2015 & 1407 & 51 & 1475 & 4 \\
& 2016 & 1512 & 62 & 1616 & 4 \\
& 2017 & 2098 & 31 & 2166 & 1 \\
\hline \multirow{6}{*}{}
\end{tabular}

\subsection{Escape history of farmed salmon}

\subsubsection{Body length at escape}

Escaped farmed salmon on the coast had a larger length at escape than escapees in the fjord (LMM: intercept (coast) estimate $( \pm \mathrm{SE})=608.22 \pm 29.45$, contrast fjord $=-37.42 \pm 12.45, t=-3.01, \mathrm{p}=0.003)$. Mean $( \pm \mathrm{SE})$ length at escape across years for escapees on the coast was $607 \pm 6 \mathrm{~mm}$, and the variation among years was 538-711 mm. Mean length at escape across years in the fjord was $557 \pm 12 \mathrm{~mm}$ and the variation among years was 456-656 mm (Fig. 3).

\subsubsection{Proportion of salmon that escaped as smolts/post-smolts}

There was no difference in the proportion of salmon that had escaped as smolt/post-smolts (length at escape $\leq 300$ ) between the coast and the fjord (GLMM logit scale: intercept (coast) estimate $( \pm \mathrm{SE})=$ $-2.62 \pm 0.37$, contrast fjord $=0.31 \pm 0.23, z=1.32, p=$ $0.19)$. On the coast the mean $( \pm \mathrm{SE})$ proportion of salmon that had escaped as smolt/post-smolts across years was $8 \pm 3 \%$, and the variation among years was $2-14 \%$. In the fjord, the mean proportion of salmon that had escaped as smolt/post-smolts across years was $11 \pm 4 \%$ and the variation among years was 4-25\% (Fig. 4).

\subsubsection{Proportion of escaped salmon with winter zones after escape}

Escaped farmed salmon caught on the coast had 0-4 winter zones after escape (Fig. 5). Percentages of escapees across years with $0,1,2,3$ or 4 winter zones were 49, 28, 20, 2 and $0.4 \%$ respectively (Fig. 5). Escapees caught in the fjord had 0-3 winter zones after escape. The percentages of escapees with $0,1,2$ and 3 winter zones after escape were 45, 30, 21 and $4 \%$ respectively.

Proportions of escapees with 1 or more winter zones after escape did not differ between the coast and the fjord (GLMM logit scale: intercept (coast) estimate $( \pm \mathrm{SE})=0.03 \pm 0.28$, contrast fjord $=0.11 \pm$ $0.15, z=0.68, p=0.50)$. On the coast the mean $( \pm \mathrm{SE})$ proportion across years was $50 \pm 10 \%$, and the variation among years was $28-78 \%$. In the fjord the mean proportion across years was $56 \pm 10 \%$ and the variation among years was 30-75\% (Fig. 6). 


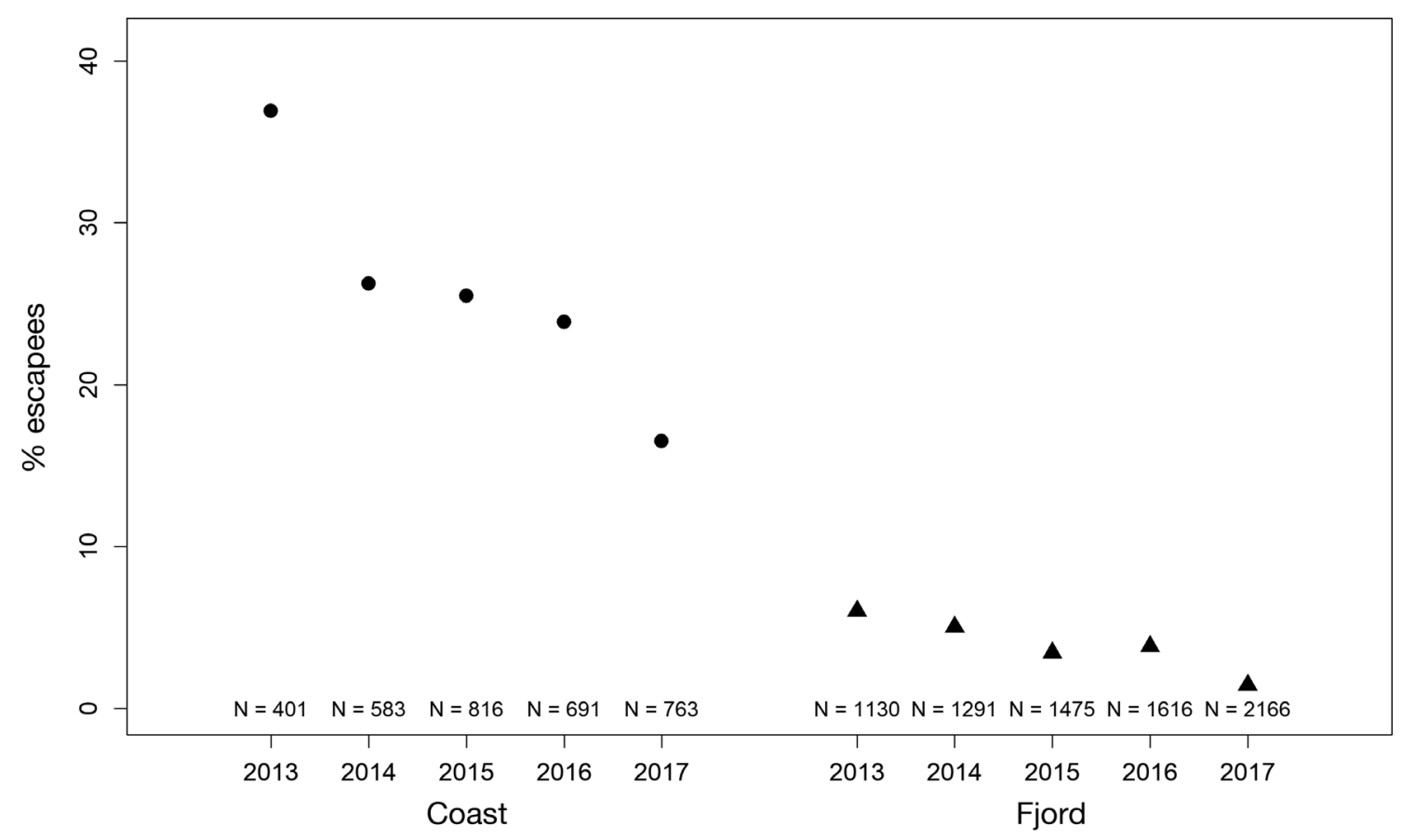

Fig. 2. Proportion of escaped farmed salmon, based on scale analysis, in catches on the coast and in the fjord from 2013 to 2017. The total number of analyzed salmon is shown on the graph for both locations in each year

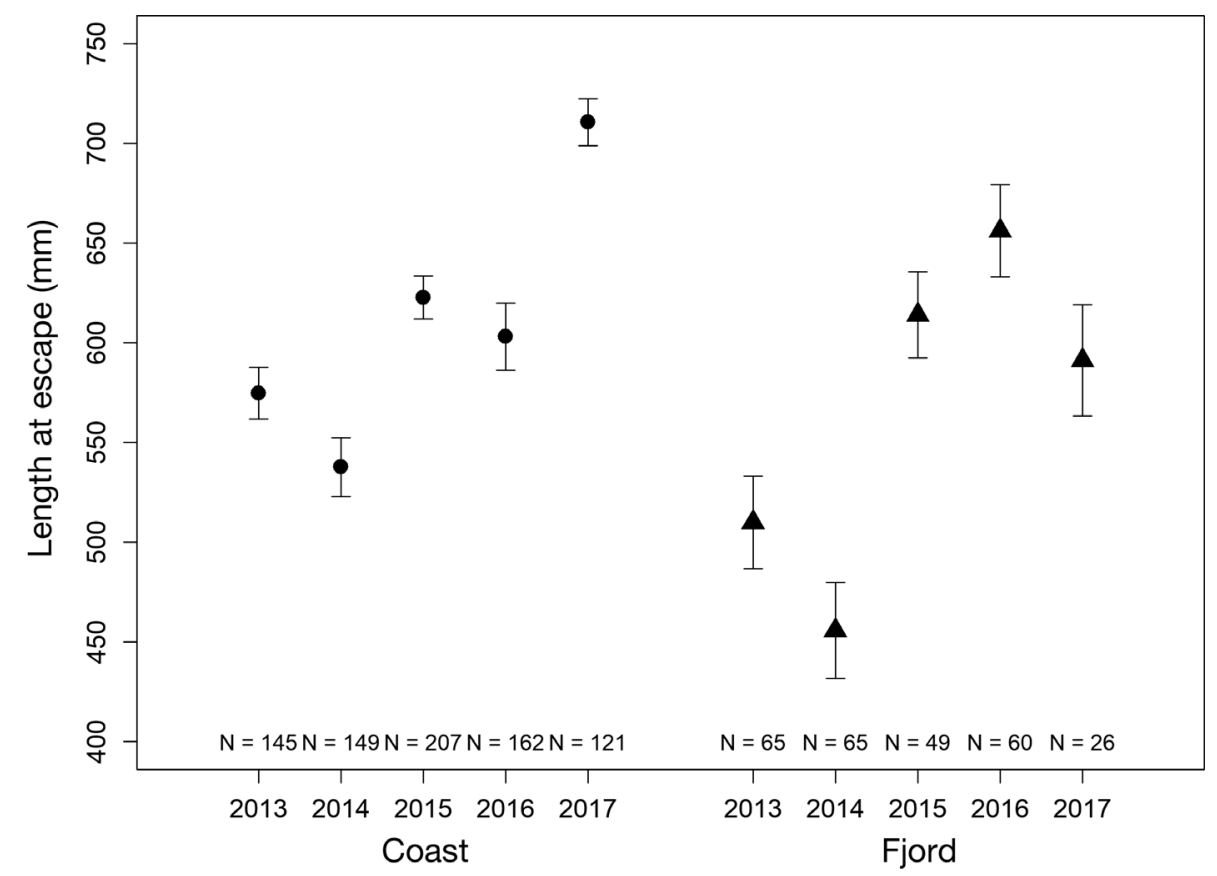

Fig. 3. Mean $( \pm$ SE) length at escape $(\mathrm{mm})$ on the coast and in the fjord from 2013 to 2017 . Sample size is given on the graph for both locations in each year

When only including salmon that escaped after some time in the sea cages (length at escape $>300 \mathrm{~mm}$ ) the overall percentages of escapees with $0,1,2,3$ and 4 winter bands on the coast were 55,27, 16, 1 and
$0.2 \%$, respectively. Overall percentages of escapees with $0,1,2$ and 3 winter bands in the fjord were 51, 33,14 and $2 \%$, respectively. There was no difference between the coast and the fjord in the proportions of 


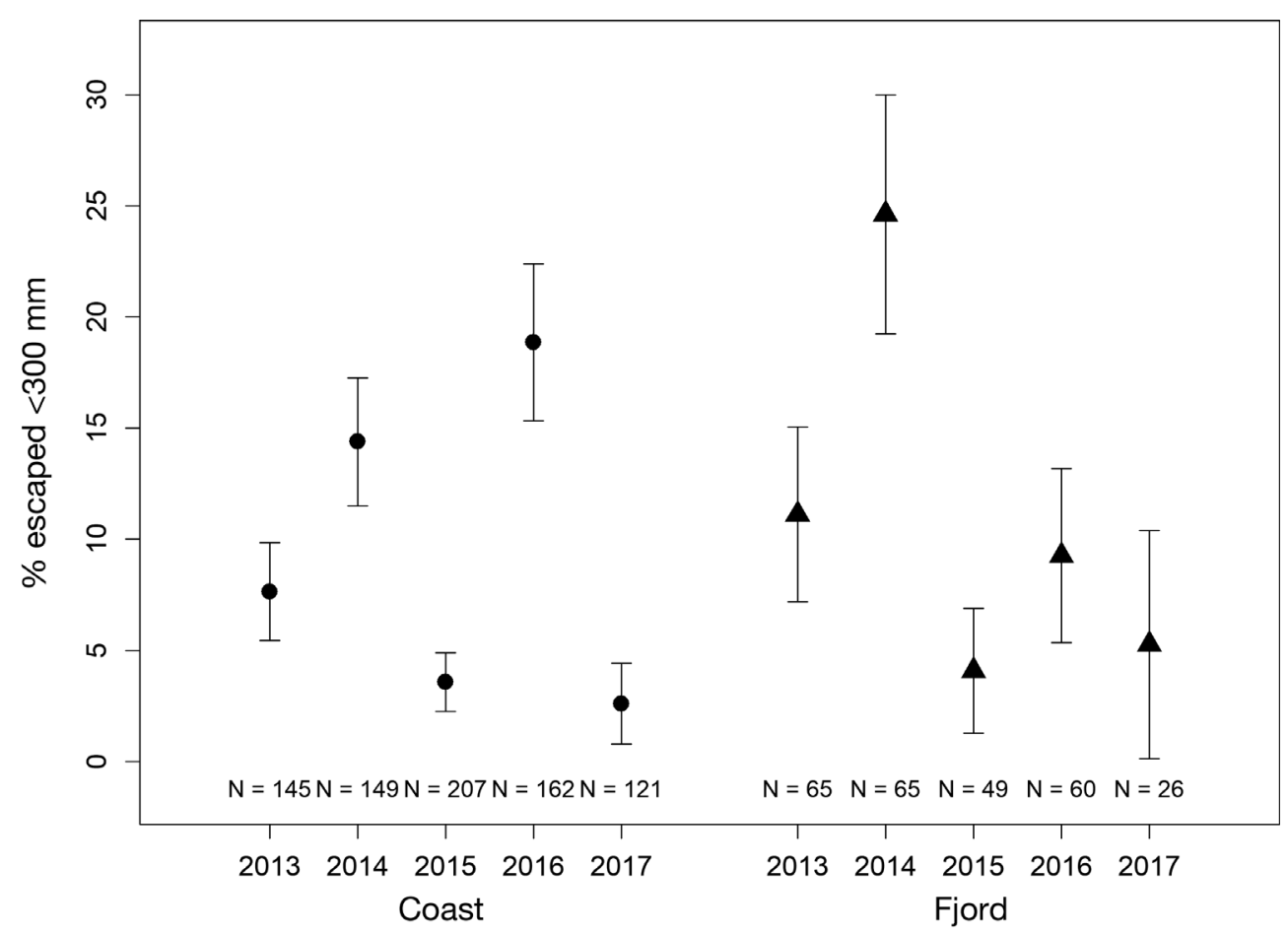

Fig. 4. Mean ( \pm SE) proportion of individuals that escaped at a length of $\leq 300$ (smolt/post-smolts) on the coast (circles) and in the fjord (triangles) from 2013 to 2017. The number of analyzed escapees is given on the graph for both locations in each year

escapees with winter bands after escape when only including escaped individuals >300 mm (GLMM logit scale: intercept (coast) estimate $( \pm \mathrm{SE})=-0.20 \pm 0.26$, contrast fjord $=0.12 \pm 0.16, z=0.70, p=0.48$ ). On the coast the mean $( \pm \mathrm{SE})$ proportion of escapees with winter bands across years was $45 \pm 2 \%$, and the variation among years was $29-74 \%$. In the fjord the mean proportion of escapees with winter bands across years was $49 \pm 3 \%$ and the variation among years was 23-72\% (Table 2).

\section{DISCUSSION}

In this study we investigated the proportion of escapees and the escape history of farmed salmon caught on the Norwegian coast and in a large adjacent salmon fjord containing a major salmon river (Namsen River). It was expected that the proportion of escaped farmed salmon would be lower in the fjord than on the coast, as not all farmed salmon in the sea are mature or maturing and will enter rivers to spawn. It was therefore also expected that the escape history of farmed salmon caught in a fjord with salmon rivers would differ from the escape history of farmed salmon caught in coastal areas.
In accordance with our expectations, the proportion of escaped farmed salmon was considerably higher on the coast (mean $=26 \%$ ) than in the fjord (mean $=4 \%$ ). A higher proportion of escaped farmed salmon in coastal waters has been observed in previous studies (Lund et al. 1991, Thorstad et al. 2008), and is likely due to differences in migration behaviour between immature and mature escapees and mortality of immature individuals before they start their spawning migration into the fjords and rivers. Immature escapees are less likely than the mature escapees to enter salmon rivers (Heggberget et al. 1993, Thorstad et al. 2008); many of the immature escaped farmed salmon may remain on the coast and contribute to the larger proportion of escapees there. In addition, a large proportion of the escapees caught on the coast may die of starvation or predation after they escape but before migrating into fjords and rivers (Whoriskey et al. 2006, Olsen \& Skilbrei 2010). It can be difficult to determine the sexual maturation status of migrating salmon, especially early in the season; data on maturation status were therefore not collected for all individuals and cannot be investigated in this study.

Farmed salmon caught on the coast had a larger length at escape (mean $=607 \mathrm{~mm}$ ) than farmed salmon caught in the fjord (mean $=557 \mathrm{~mm}$ ). However, the 

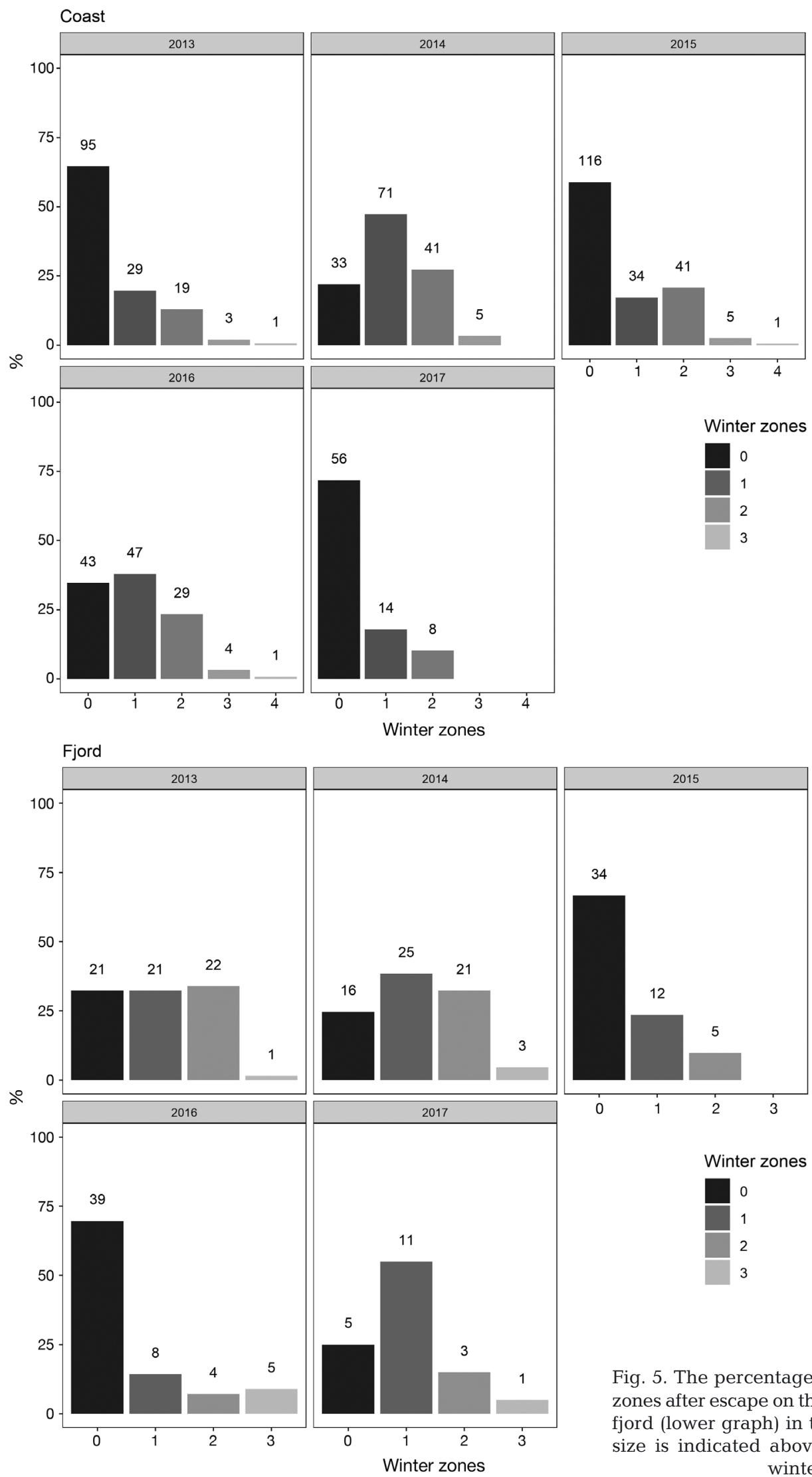

Fig. 5. The percentage of individuals with $0-4$ winter zones after escape on the coast (upper graph) and in the fjord (lower graph) in the years 2013 to 2017. Sample size is indicated above the bar for each number of winters in the wild 


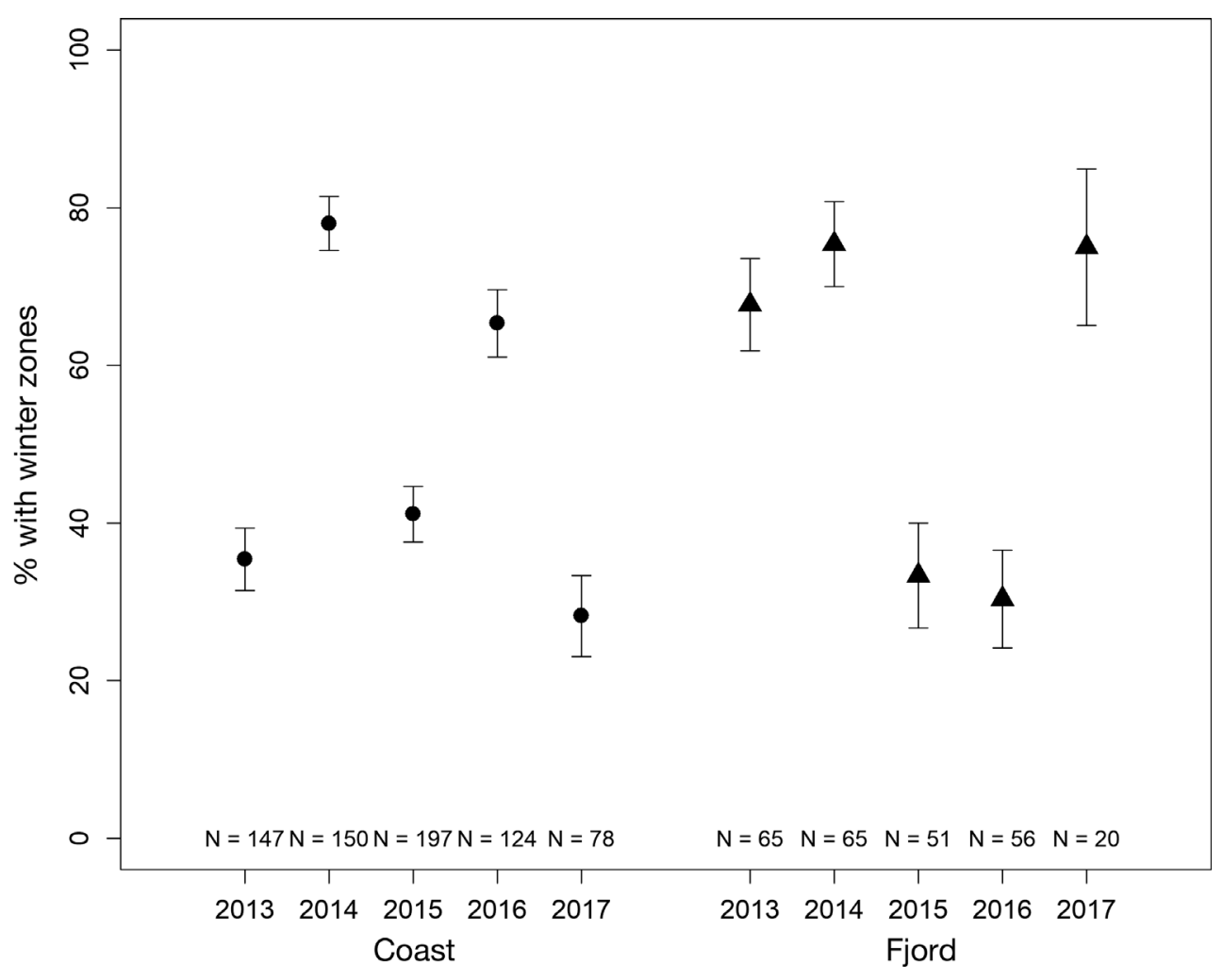

Fig. 6. Mean $( \pm$ SE) percentage of individuals with 1 or more winter zones after escape on the coast and in the fjord from 2013 to 2017. The number of escapees with sufficient sample quality to analyze the number of winter zones in the growth pattern is given on the graph for both locations in each year

difference in the average size at escape between the localities was small ( $\approx 50 \mathrm{~mm})$, and furthermore, the proportion of salmon that escaped at a size $\leq 300 \mathrm{~mm}$ did not differ between the coast (mean $=8 \%$ ) and the fjord $($ mean $=11 \%)$. This suggests that there were no major difference in the age at escape between the 2 locations.

Even though the proportion of farmed salmon that escaped as smolts/post-smolts varied between years ( $2-14 \%$ on the coast and $4-25 \%$ in the fjord), the proportions were relatively low at both locations in the studied years (2013-2017). The Namsfjord is a national salmon fjord and the Namsen River is a national salmon river. The national salmon fjords were established to secure an area of protection for wild salmon populations (NOU 1999, Aasetre \& Vik 2013). As a consequence there are no fish farms within the Namsfjord (Fig. 1). Combined with previous experiments showing that farmed or cultured salmon allowed to escape as smolts/post-smolts return to the area of escape to some extent (Hansen \& Jonsson 1989, 1991, Skilbrei 2010a), this may explain why few farmed salmon caught in the fjord had escaped as smolts/post-smolts. There is, however, farming activity in close proximity to the national salmon fjord (Fig. 1), and there was no difference between the coast and the fjord in the proportion of farmed salmon that escaped at a size $\leq 300$ $\mathrm{mm}$. This indicates that relatively few farmed salmon escaped as smolts/post-smolts in our study area between 2013 and 2017.

The proportion of farmed salmon showing one or more winter zones after escape in their scales also

Table 2. Sample size $(\mathrm{N})$ and mean $( \pm \mathrm{SE})$ proportion of individuals with 1 or more winter zones after escape of adult farmed salmon caught on the coast and in the fjord from 2013 to 2017

\begin{tabular}{|lccc|}
\hline Locality & Year & N & $\begin{array}{c}\text { Mean } \pm \text { SE \% with } \\
\text { winter zones }\end{array}$ \\
\hline Coast & 2013 & 133 & $29 \pm 4$ \\
& 2014 & 125 & $73 \pm 4$ \\
& 2015 & 189 & $39 \pm 4$ \\
& 2016 & 99 & $57 \pm 5$ \\
Fjord & 2017 & 75 & $27 \pm 5$ \\
& 2013 & 56 & $63 \pm 7$ \\
& 2014 & 49 & $67 \pm 7$ \\
& 2015 & 47 & $32 \pm 7$ \\
& 2016 & 49 & $23 \pm 6$ \\
& 2017 & 18 & $72 \pm 11$ \\
\hline
\end{tabular}


did not differ between the coast (mean $=50 \%$ ) and the fjord $($ mean $=56 \%$ ). Based on the assumption that escapees in the fjord mostly consist of maturing or mature salmon on their spawning migration and that immature salmon escape every year, we expected that there would be a higher proportion of salmon that had spent a longer time in the wild after escape in the fjord than on the coast. Newly escaped smolts/post-smolts were not caught because the mesh size of the bag nets we used $(58 \mathrm{~mm}$ ) catches few salmon smaller than $57 \mathrm{~cm}$ (T. F. Næsje et al. unpubl.). Our estimates of newly escaped farmed salmon are therefore based on farmed salmon that escaped after the smolt/post-smolt stage. However, repeating the analysis without the individuals that escaped at a length $\leq 300 \mathrm{~mm}$ did not change our results, as there was no difference between the coast and the fjord in the proportion of escapees with 1 or more winter zones (coast mean $=45 \%$, and fjord mean $=49 \%$ ). The proportion of newly escaped salmon, especially on the coast, is expected to vary between years, as it is sensitive to escape events at local salmon farms. The proportion of salmon with 1 or more winter zones after escape varied from $28-78 \%$ on the coast and 30-75\% in the fjord between 2013 and 2017. In 2013, the proportion was $35 \%$ on the coast and $68 \%$ in the fjord, in 2016, the proportion was $65 \%$ on the coast and $30 \%$ in the fjord and in 2017 the proportion was $28 \%$ on the coast and $75 \%$ in the fjord. Based on this observation the proportion of newly escaped farmed salmon on the coast does not necessarily reflect the proportion of newly escaped salmon in the fjord (or most likely in the river).

Independent of location, a relatively large proportion of the adult escapees (>300 mm at escape) caught in this study survived at least one winter in the sea after escape ( $\geq 1$ winter zones in the growth pattern in the scales), and some spent up to $3 \mathrm{yr}$ in the sea after escape. This is an important finding, since little is known about the fate of adult escapees in the wild. Adult farmed salmon released from fish farms just before the spawning period will likely have low reproductive success (Fleming et al. 1996). But to our knowledge, no information is available on the reproductive success of adult farmed salmon that have spent a long time in the wild.

Fatty acid profiling has been used to distinguish newly escaped farmed salmon from fish that have been in the wild for some time in the Hardangerfjord and nearby coast (Skilbrei et al. 2015b). Skilbrei et al. (2015b) found that $24 \%$ of the farmed salmon had escaped early and likely as smolts/early post-smolts, while $61 \%$ had escaped recently as adults, presum- ably in the same year they were caught. This is in the same range as the highest reported proportion of early escapees in our study $(25 \%$ in the fjord in 2014). Only $15 \%$ had escaped at a larger size than smolt/post-smolt without being classified as recently escaped (Skilbrei et al. 2015b). Other studies using the same method found that 91 and $100 \%$ of the escapees caught in the Etne River in southwestern Norway had escaped the same year they were caught (Quintela et al. 2016, Madhun et al. 2017). In our study, using only escapees where both the number of winter zones after escape and size at escape could be determined, on the coast $50 \%$ of escaped farmed salmon escaped as adults in the same year they were caught, $41 \%$ escaped as adults and had spent at least 1 winter in the sea before they were caught, and $9 \%$ had escaped as smolts/post-smolts and had spent at least 1 winter in the sea after escape. Similarly, in the fjord $45 \%$ of escapees had escaped as adults and were caught in the same year as they escaped, $43 \%$ escaped as adults and had spent at least 1 winter in the sea before they were caught, and $12 \%$ had escaped as smolts/post-smolts and had spent at least 1 winter in the sea after escape. Our study found a higher proportion of farmed escapees that had survived at least 1 winter in the sea after escape than Skilbrei et al. (2015b). Differences in study areas and methodology could have contributed to the contrasting results.

Few studies have used scale analysis to determine escape history. Two studies have concluded that it is difficult to determine the escape history of farmed salmon based on scale reading (Erkinaro et al. 2010, Skilbrei et al. 2015b). Accurate scale reading is highly dependent on the scale reader's skills and experience interpreting different growth patterns; hence, it is difficult to compare our study to these other studies. The scales used in our study were analyzed by an experienced technician who has worked with scales from wild and farmed salmon for several decades. Furthermore, we were conservative when using the scale analysis, excluding data when the length at escape or time in the wild after escape were uncertain. The main challenge when determining time of escape based on scales is that there might be weak growth checks (irregularity in circuli spacing) in the growth pattern, likely due to reduced growth after disease outbreaks and treatments for salmon lice Lepeophtheirus salmonis. As a test, we read scale samples from fish taken from 5 batches of farmed salmon from 5 different farm sites (T. Aronsen et al. unpubl.), to see whether the patterns we find in escapees that have spent a winter in the wild could 
be found in salmon sampled from a net pen. In 1 of the 5 batches (batch = salmon sampled from the same net pen), 14 of the 86 salmon sampled had a pattern of slow growth in the scales that could resemble the slow growth after escape (a winter in the sea after escape). For this specific batch, winters at sea after escape were uncertain (the technician reading the scales was unable to determine whether there were growth checks indicating escape) for an additional 16 individuals due to inconsistencies in the growth pattern. For the remaining 388 farmed salmon sampled from the other 4 farms, none of the individuals had scale patterns resembling escapees that had spent a winter in the sea. Based on these findings, we believe that our results for length at escape and number of winters in the sea after escape are accurate for most individuals, and give important information on the post escape life history of escapees.

To our knowledge, the present study is the only one to have compared variation in the life history of escaped farmed salmon between locations and across years. The escape history of farmed Atlantic salmon will influence the likelihood of escapees reaching maturity and entering the rivers to spawn with wild salmon or other escapees. Our study found no difference in the escape history of farmed salmon caught on the coast or in an adjacent fjord. Instead, we found that the farmed salmon both on the coast and in the fjord included both recently escaped salmon and salmon that had spent several years in the sea after escape. Although we found no major differences between locations in escape history, the higher proportion of escapees on the coast suggests that there is a reservoir of immature farmed salmon in coastal waters, and individuals may enter rivers to spawn with wild salmon when they reach sexual maturity. Hence, when investigating the risk of genetic introgression from escapees to wild salmon populations, escape events from the last 4 yr will have to be considered.

Acknowledgements. This study was supported financially by the Research Council of Norway through the NINA Strategic Institute Initiative 'Interactions between aquaculture and wild salmonids', the Norwegian Environmental Agency, the County Governor of Trøndelag (special thanks to Anton Rikstad) and the Norwegian Directorate of Fisheries. We are grateful to Gunnel Østborg, Jan Gunnar Jensås, Sigrid Skoglund and Laila Saksgård for performing the scale analysis and Leif Skorstad and Ivan Kvalø for data collection.

\section{LITERATURE CITED}

Aasetre J, Vik J (2013) Framing the environment - Disputes and developments in the management of Norwegian salmon fjords. Ocean Coast Manage 71:203-212
Anon (2018a) Rømt oppdrettslaks i vassdrag. Rapport fra det nasjonale overvåkingsprogrammet 2017. Fisken og havet særnr.2-2018:1-69. https://www.hi.no/resources/ publikasjoner/romt-oppdrettslaks-i-vassdrag/2018/romt_ laks_fisken_og_havet_2018.pdf

Anon (2018b) Status for norske laksebestander i 2018. Rapport fra Vitenskapelig råd for lakseforvaltning 11. https://brage.nina.no/nina-xmlui/handle/11250/2503390

Bates D, Machler M, Bolker BM, Walker SC (2015) Fitting linear mixed-effects models using lme4. J Stat Softw 67: $1-48$

* Bolstad GH, Hindar K, Robertsen G, Jonsson B and others (2017) Gene flow from domesticated escapes alters the life history of wild Atlantic salmon. Nat Ecol Evol 1:0124

* Diserud OH, Fiske P, Sægrov H, Urdal K and others (2019) Escaped farmed Atlantic salmon in Norwegian rivers during 1989-2013. ICES J Mar Sci 76:1140-1150

*Erkinaro J, Niemela E, Vaha JP, Primmer CR, Brors S, Hassinen E (2010) Distribution and biological characteristics of escaped farmed salmon in a major subarctic wild salmon river: implications for monitoring. Can J Fish Aquat Sci 67:130-142

Fiske P, Lund RA, Hansen LP (2005) Identifying fish farm escapees. In: Cadrin SX, Friedland KD, Waldman JR (eds) Stock identification methods: applications in fishery science. Elsevier Academic Press, Amsterdam, p 659-680

Fiske P, Lund RA, Hansen LP (2006) Relationships between the frequency of farmed Atlantic salmon, Salmo salar L., in wild salmon populations and fish farming activity in Norway, 1989-2004. ICES J Mar Sci 63:1182-1189

* Fleming IA, Jonsson B, Gross MR, Lamberg A (1996) An experimental study of the reproductive behaviour and success of farmed and wild Atlantic salmon (Salmo salar). J Appl Ecol 33:893-905

Fleming IA, Lamberg A, Jonsson B (1997) Effects of early experience on the reproductive performance of Atlantic salmon. Behav Ecol 8:470-480

*Fleming IA, Hindar K, Mjølnerød IB, Jonsson B, Balstad T, Lamberg A (2000) Lifetime success and interactions of farmed salmon invading a native population. Proc R Soc B 267:1517-1523

Forseth T, Barlaup BT, Finstad B, Fiske P and others (2017) The major threats to Atlantic salmon in Norway. ICES J Mar Sci 74:1496-1513

*Gausen D, Moen V (1991) Large-scale escapes of farmed Atlantic salmon (Salmo salar) into Norwegian rivers threaten natural populations. Can J Fish Aquat Sci 48: 426-428

Glover KA, Pertoldi C, Besnier F, Wennevik V, Kent M, Skaala O (2013) Atlantic salmon populations invaded by farmed escapees: quantifying genetic introgression with a Bayesian approach and SNPs. BMC Genet 14:74

Glover KA, Solberg MF, McGinnity P, Hindar K and others (2017) Half a century of genetic interaction between farmed and wild Atlantic salmon: status of knowledge and unanswered questions. Fish Fish 18:890-927

* Glover KA, Urdal K, Næsje T, Skoglund H and others (2019) Domesticated escapees on the run: the second-generation monitoring programme reports the numbers and proportions of farmed Atlantic salmon in $>200$ Norwegian rivers annually. ICES J Mar Sci 76:1151-1161

Hansen LP (2006) Migration and survival of farmed Atlantic salmon (Salmo salar L.) released from two Norwegian fish farms. ICES J Mar Sci 63:1211-1217 
Hansen LP, Jonsson B (1989) Salmon ranching experiments in the river Imsa: effect of timing of Atlantic salmon (Salmo salar) smolt migration on survival to adults. Aquaculture 82:367-373

Hansen LP, Jonsson B (1991) The effect of timing of Atlantic salmon smolt and post-smolt release on the distribution of adult return. Aquaculture 98:61-67

Hansen LP, Youngson AF (2010) Dispersal of large farmed Atlantic salmon, Salmo salar, from simulated escapes at fish farms in Norway and Scotland. Fish Manag Ecol 17: 28-32

Hansen LP, Jacobsen JA, Lund RA (1993) High numbers of farmed Atlantic salmon, Salmo salar L., observed in oceanic waters north of the Faroe Islands. Aquacult Fish Manage 24:777-781

Heggberget TG, Økland F, Ugedal O (1993) Distribution and migratory behaviour of adult wild and farmed Atlantic salmon (Salmo salar) during return migration. Aquaculture 118:73-83

Hindar K, Ryman N, Utter F (1991) Genetic effects of aquaculture on natural fish populations. Aquaculture 98:259-261

ICES (2011) Report of the workshop on age determination of salmon (WKADS). 18-20 January 2011, Galway. ICES CM 2011/ACOM:44

Jacobsen JA, Hansen LP (2001) Feeding habit of wild and escaped farmed Atlantic salmon, Salmo salar L., in the Northeast Atlantic. ICES J Mar Sci 58:916-933

Jensen AJ, Johnsen BO (1982) Difficulties in aging Atlantic salmon (Salmo salar) and brown trout (Salmo trutta) from cold rivers due to lack of scales as yearlings. Can J Fish Aquat Sci 39:321-325

Jensen AJ, Karlsson S, Fiske P, Hansen LP, Hindar K, Ostborg GM (2013) Escaped farmed Atlantic salmon grow, migrate and disperse throughout the Arctic Ocean like wild salmon. Aquacult Environ Interact 3:223-229

Jonsson B, Jonsson N (2006) Cultured Atlantic salmon in nature: a review of their ecology and interactions with wild fish. ICES J Mar Sci 63:1162-1181

Jørgensen KM, Solberg MF, Besnier F, Thorsen A and others (2018) Judging a salmon by its spots: environmental variation is the primary determinant of spot patterns in Salmo salar. BMC Ecol 18:14

Karlsson S, Moen T, Hindar K (2010) Contrasting patterns of gene diversity between microsatellites and mitochondrial SNPs in farm and wild Atlantic salmon. Conserv Genet 11:571-582

Karlsson S, Diserud O, Fiske P, Hindar K (2016) Widespread genetic introgression of escaped farmed Atlantic salmon in wild salmon populations. ICES J Mar Sci 73:2488-2498

Kuznetsova A, Brockhoff PB，Christensen RHB (2017) lmerTest package: tests in linear mixed effects models. J Stat Softw 82:1-26

Lund RA, Hansen LP (1991) Identification of wild and reared Atlantic salmon, Salmo salar L., using scale characters. Aquacult Fish Manage 22:499-508

Lund RA, Økland F, Hansen LP (1991) Farmed Atlantic salmon (Salmo salar) in fisheries and rivers in Norway. Aquaculture 98:143-150

* Madhun AS, Wennevik V, Skilbrei OT, Karlsbakk E and others (2017) The ecological profile of Atlantic salmon escapees entering a river throughout an entire season: diverse in escape history and genetic background, but frequently virus-infected. ICES J Mar Sci 74: 1371-1381
McGinnity P, Prodöhl P, Ferguson A, Hynes R and others (2003) Fitness reduction and potential extinction of wild populations of Atlantic salmon, Salmo salar, as a result of interactions with escaped farm salmon. Proc R Soc B 270:2443-2450

* Mjølnerød IB, Refseth UH, Karlsen E, Balstad T, Jakobsen KS, Hindar K (1997) Genetic differences between two wild and one farmed population of Atlantic salmon (Salmo salar) revealed by three classes of genetic markers. Hereditas 127:239-248

Moe K, Naesje TF, Haugen TO, Ulvan EM, Aronsen T, Sandnes T, Thorstad EB (2016) Area use and movement patterns of wild and escaped farmed Atlantic salmon before and during spawning in a large Norwegian river. Aquacult Environ Interact 8:77-88

NOU (1999) Til laks åt alle kan ingen gjera? Whitepaper 1999:9, Norwegian Ministry of Climate and Environment, Oslo

Olsen RE, Skilbrei OT (2010) Feeding preference of recaptured Atlantic salmon Salmo salar following simulated escape from fish pens during autumn. Aquacult Environ Interact 1:167-174

* Quintela M, Wennevik V, Sorvik AGE, Skaala O and others (2016) Siblingship tests connect two seemingly independent farmed Atlantic salmon escape events. Aquacult Environ Interact 8:497-509

R Core Team (2017) R: a language and environment for statistical computing. R Foundation for Statistical Computing, Vienna

* Skaala O, Hoyheim B, Glover K, Dahle G (2004) Microsatellite analysis in domesticated and wild Atlantic salmon (Salmo salar L.): allelic diversity and identification of individuals. Aquaculture 240:131-143

* Skaala O, Taggart JB, Gunnes K (2005) Genetic differences between five major domesticated strains of Atlantic salmon and wild salmon. J Fish Biol 67:118-128

* Skaala O, Wennevik V, Glover KA (2006) Evidence of temporal genetic change in wild Atlantic salmon, Salmo salar L., populations affected by farm escapees. ICES J Mar Sci 63:1224-1233

* Skaala O, Glover KA, Barlaup BT, Svasand T, Besnier F, Hansen MM, Borgstrom R (2012) Performance of farmed, hybrid, and wild Atlantic salmon (Salmo salar) families in a natural river environment. Can J Fish Aquat Sci 69: 1994-2006

Skilbrei OT (2010a) Adult recaptures of farmed Atlantic salmon post-smolts allowed to escape during summer. Aquacult Environ Interact 1:147-153

* Skilbrei OT (2010b) Reduced migratory performance of farmed Atlantic salmon post-smolts from a simulated escape during autumn. Aquacult Environ Interact 1: $117-125$

Skilbrei OT, Jørgensen T (2010) Recapture of cultured salmon following a large-scale escape experiment. Aquacult Environ Interact 1:107-115

Skilbrei OT, Holst JC, Asplin L, Mortensen S (2010) Horizontal movements of simulated escaped farmed Atlantic salmon (Salmo salar) in a western Norwegian fjord. ICES J Mar Sci 67:1206-1215

* Skilbrei OT, Heino M, Svasand T (2015a) Using simulated escape events to assess the annual numbers and destinies of escaped farmed Atlantic salmon of different life stages from farm sites in Norway. ICES J Mar Sci 72: 670-685

* Skilbrei OT, Normann E, Meier S, Olsen RE (2015b) Use of 
fatty acid profiles to monitor the escape history of farmed Atlantic salmon. Aquacult Environ Interact 7:1-13

Taranger GL, Karlsen O, Bannister RJ, Glover KA and others (2015) Risk assessment of the environmental impact of Norwegian Atlantic salmon farming. ICES J Mar Sci 72: 997-1021

Thorstad EB, Fleming IA, McGinnity P, Soto D, Wennevik V, Whoriskey $F$ (2008) Incidence and impacts of escaped

Editorial responsibility: Kevin Glover, Bergen, Norway farmed Atlantic salmon Salmo salar in nature. Report No. 36, NINA, Trondheim

* Warner K, Havey K (1961) Body-scale relationship in landlocked salmon, Salmo salar. Trans Am Fish Soc 90:457-461

*Whoriskey FG, Brooking P, Doucette G, Tinker S, Carr JW (2006) Movements and survival of sonically tagged farmed Atlantic salmon released in Cobscook Bay, Maine, USA. ICES J Mar Sci 63:1218-1223

Submitted: February 13, 2020 ; Accepted: July 3, 2020

Proofs received from author(s): August 23, 2020 